\title{
Weed control and crop selectivity of post-emergence herbicides in common beans
}

\author{
Lucas De Ross Marchioretto $^{I^{*}}$ Taísa Dal Magro
} IUniversidade de Caxias do Sul (UCS), Av. Dom Frei Cândido Maria Bampi, 2800, Bairro Barcelos, 95200-000, Vacaria, RS, Brasil. E-mail:
lucasdeross@hotmail.com. "Corresponding author.

ABSTRACT: There are few options of wide spectrum selective herbicides registered for post-emergence weed control in common beans crop. The experiment aimed to test crop selectivity and weed control of post-emergence herbicides on common beans. Weed control, injury and grain yield were evaluated. Treatments consisted on: cloransulam-methyl, imazethapyr, fomesafen, bentazon and diclosulam isolated and tank-mixed with clethodim; imazamox+bentazon, fomesafen+fluazifop, clethodim; cloransulam+bentazon and imazethapyr+bentazon. Treatments were tested on the cultivars 'ANfc 9', 'IPR Uirapuru' and 'BRS Estilo'. The high-yielding treatments to the cultivar 'ANfc 9'were fomesafen alone and tank-mixed with clethodim or fluazifop, cloransulam and diclosulam tank-mixed with clethodim, and imazamox+bentazon. The highyielding treatments with the cultivar 'IPR Uirapuru' was fomesafen tank-mixed with clethodim or fluazifop. High-yielding treatment to BRS Estilo was fomesafen+fluazifop. Bidens pilosa was controlled by all the treatments with broadleaf herbicides with exception of imazethapyr. Digitaria spp. was controlled by all treatments containing clethodim, fluazifop, fomesafen and imazethapyr. Treatments with cloransulam, diclosulam, fomesafen and imazamox were efficient to control Parthenium hysterophorus.

Key words: 'ANfc 9', 'BRS Estilo', chemical control, 'IPR Uirapuru', Phaseolus vulgaris.

Controle de plantas daninhas e seletividade de herbicidas pós-emergentes na cultura do feijão

RESUMO: Na cultura do feijão, há poucas opções de herbicidas seletivos com amplo espectro de controle de plantas daninhas para uso em pós-emergência da cultura. O presente experimento teve por objetivo testar a seletividade e o controle de plantas daninhas na pós-emergência da cultura do feijão. Foram testados os herbicidas clethodim, cloransulam, imazethapyr, fomesafen, bentazon e diclosulam, isoladamente e em associação com clethodim, imazamox+bentazon, fomesafen+fluazifop, cloransulam+bentazon e imazethapyr+bentazon nas cultivares de 'feijão ANfc 9', 'BRS Estilo'e 'IPR Uirapuru'. Foram analisadas: fitotoxidez e controle de plantas daninhas e produtividade. O Bidens pilosa foi controlado com todos os tratamentos contendo herbicidas latifolicidas, exceto imazethapyr. Digitaria spp. foi controlada em todos os tratamentos com clethodim, fluazifop, fomesafen e imazethapyr. Os tratamentos contendo cloransulam, diclosulam, fomesafen e imazamox foram eficientes no controle de Parthenium hysterophorus. A cultivar 'ANfc 9'é mais produtiva nos tratamentos com cloransulam e diclosulam associados com clethodim, fomesafen isolado ou associado ao clethodim ou fluazifop e, imazamox+bentazon. A cultivar 'IPR Uirapuru' foi mais produtiva com fomesafen associado ao clethodim ou fluazifop e 'BRS Estilo'foi mais produtiva com fomesafen associado fluazifop. Palavras-chave: 'ANfc 9', 'BRS Estilo', controle químico, 'IPR Uirapuru', Phaseolus vulgaris.

\section{INTRODUCTION}

Selective herbicides have to control weeds and cause no crop injury that could eventually cause yield reduction. Chemical control consists on the use of substances that once the weed leaves, stems or roots absorb it, the metabolism is negatively affected leading to complete necrosis of weeds or a severe reduction on the weed development up to a growth stage that does not compete with the crop for water and nutrients (CONSTANTIN, 2011).

Weed competition negatively affects common beans yield at the growth stages between V4 and R6, which should be totally weed free
(KOZLOWSKI et al., 2002). Current troublesome weeds in common beans crop at the Campos de Cima da Serra region are: Ipomoea spp., Parthenium hysterophorus, Euphorbia heterophylla, Conyza spp., Raphanus spp., Digitaria spp., Eleusine indica and Bidens pilosa.

The selective herbicides registered to post-emergence weed control on common beans crop in Brazil are imazamox+bentazon (sold as a combination), bentazon, and fomesafen to broadleaf weeds control, clethodim to annual grasses control, and imazethapyr for controlling both grasses and broadleaf weeds control (AGROFIT, 2015). The registered herbicides commonly used on common 
beans are reported as safe and effective to weed control. Bentazon causes visual injury of $1,4 \%$ to black beans at 14 days after treatment (DAT), $3 \%$ to mung beans at 20 DAT; although, no yield reduction was reported (BAUER et al., 1995b; FONTES et al, 2001; SOLTANI et al., 2005). Imazethapyr at the registered rate causes elevated visual injury in common beans at 14 DAT, but it does not reduce crop yield; in contrast, the rate of $212 \mathrm{~g}$ a.i. $\mathrm{ha}^{-1}$ causes yield reduction of 54\% (BAUER et al., 1995b). The same authors reported that imazethapyr tank mixed with bentazon decreased the crop injury of common beans.

The herbicides fomesafen, imazamox and the graminicides clethodim and fluazifop are extensively reported as highly crop selective to common beans. Many studies supported that these herbicides cause low crop injury and little negative interference on the cropping yield on black, white and pinto beans (FONTES et al., 2001; HEKMAT et al., 2008; SOLTANI et al., 2013; LINHARES et al., 2014). However, imazamox at the rate of $129 \mathrm{~g}$ a.i. ha $^{-1}$ reduced grain yield of mung beans (FONTES et al., 2001).

Cloransulam is registered to control broadleaf weeds in soybeans crop in Brazil (AGROFIT, 2015). However, there are studies about the potential use of this herbicide on post-emergence weed control on common beans crop. Cloransulam at the rate of $17,5 \mathrm{~g}$ a.i. ha ${ }^{-1}$ is reported to cause crop injury of $8 \%$ at $14 \mathrm{DAT}$ on common beans, yet yield loss ranging from 29 to $43 \%$ (SOLTANI et al., 2013). The herbicide cloransulam has the potential to be used in common beans when tank mixed with bentazon, which promoted a safening (protects) effect on acetolactate synthase (ALS) herbicides by decreasing the rate of absorption and translocation throughout the plant; moreover, tank-mixing imazethapyr or cloransulam with bentazon, amplified the weed control spectrum (SOLTANI et al., 2012; SOLTANI et al., 2013). Diclosulam belongs to the group of the triazolopyrimidine, which is the same of the herbicide cloransulam (OLIVEIRA JR., 2011). Thereby, diclosulam has the potential to be used as a post-emergence herbicide on common beans.

There is currently little information about varietal sensitivity of common beans and weed control spectrum of post-emergence broadleaf herbicides associations with acetyl CoA carboxylase (ACCase) herbicides. The objective of this study was to evaluate the most effective post-emergence herbicides associations on weed control and crop selectivity on three cultivars of common beans: 'ANfc 9', 'IPR Uirapuru' and 'BRS Estilo'.

\section{MATERIALS AND METHODS}

The field experiment was carried out at the State Foundation of Agricultural Research (FEPAGRO), located at the municipality of Vacaria-RS, Brazil. The experimental area was left fallow (without weed control) for three years, and the weed was uncontrolled during this period. The weeds present in the experimental site were: Bibens pilosa, Digitaria spp., Parthenium hysterophorus and Ipomoea spp.

The experimental design used was randomized blocks with 17 treatments and four replications. Each plot was two meters wide and five meters long, totalizing $10 \mathrm{~m}^{2}$. The edges $(0.5 \mathrm{~m})$ was discarded totalizing a final area of $4 \mathrm{~m}^{2}$. Fifteen days before the sowing day (Dec 09, 2014), the area was desiccated with glyphosate at a rate of $1440 \mathrm{~g}$ a.i. ha ${ }^{-1}$, to assure the area was weed-free.

The variables visual injury and grain yield were conducted in a factorial arrangement $3 \times 17$, where three cultivars of common beans were sowed: 'ANfc 9', 'IPR Uirapuru' and 'BRS Estilo', and 17 treatments were tested: imazamox+bentazon $\quad\left(28+600 \mathrm{~g} \quad\right.$ a.i. ha $\left.^{-1}\right)$, bentazon $\left(720 \mathrm{~g}\right.$ a.i. ha $\left.{ }^{-1}\right)$, fomesafen $(250 \mathrm{~g}$ a.i. $\left.\mathrm{ha}^{-1}\right)$, fomesafen+fluazifop-p-buthyl $(250+250 \mathrm{~g}$ a.i. ha $\left.^{-1}\right)$, cloransulam-methyl (17,5g a.i. ha $\left.{ }^{-1}\right)$, clethodim (108g a.i. ha-1), diclosulam (35g a.i. ha $\left.{ }^{-1}\right)$, imazethapyr $\left(100 \mathrm{~g}\right.$ a.i. ha $\left.{ }^{-1}\right)$, clethodim+bentazon $\left(108+720 \mathrm{~g}\right.$ a.i. ha $\left.\mathrm{ha}^{-1}\right)$, clethodim+fomesafen $\left(108+250 \mathrm{~g}\right.$ a.i. $\left.\mathrm{ha}^{-1}\right)$, clethodim+cloransulam-methyl $\left(108+17,5 \mathrm{~g}\right.$ a.i. ha $\left.{ }^{-1}\right)$, clethodim+diclosulam $(108+35 \mathrm{~g}$ a.i. ha $\left.^{-1}\right)$, clethodim+imazethapyr $\left(108+100 \mathrm{~g}\right.$ a.i. ha $\left.{ }^{-1}\right)$, cloransulam-methyl+bentazon $\left(17,5+720 \mathrm{~g}\right.$ a.i. ha $\left.{ }^{-1}\right)$, imazethapyr+bentazon $\left(100+720 \mathrm{~g}\right.$ a.i. ha $\left.{ }^{-1}\right)$, a nontreated weedy control, and a weed-free control.

The herbicides were sprayed on Dec 30, 2014 when the crop was at V2 growth stage, and all the weeds had from two to four leaves, with a $\mathrm{CO}_{2}$ pressurized backpack sprayer calibrated to deliver $150 \mathrm{~L} \mathrm{ha}^{-1}$ of water volume, at $2.5 \mathrm{kgf} \mathrm{cm}^{-2}$. Boom was $2 \mathrm{~m}$ wide with four XR 110.02 nozzle tips. The air temperature was at $24^{\circ} \mathrm{C}$ and the air humidity was at $77 \%$.

Injury was visually evaluated into a scale ranging from 0 to $100(0=$ no injury and $100=$ total necrosis) comparing it to the weed-free control, at 14 days after treatment (DAT). Weed control was evaluated visually at 28DAT into a scale ranging from 0 to $100(0=$ no control and $100=$ total necrosis $)$ comparing it to the non-treated weedy control. Grain yield was determined by harvesting the final area, 
and correcting grain humidity to $13 \%$. Data were extrapolated to $\mathrm{kg} \mathrm{ha}^{-1}$.

All data were subjected to analysis of variance $(\mathrm{P} \leq 0,05)$ using ASSISTAT statistical software, and when the treatments were significant, the means comparisons were made using Scott \& Knott test $(\mathrm{P} \leq 0,05)$.

\section{RESULTS AND DISCUSSIONS}

B. pilosa was controlled by all the treatments containing a broadleaf herbicide with exception of imazethapyr alone or tank-mixed with clethodim. (Table 1). This result differed from FONTES et al. (2001) that concluded that fomesafen+fluazifop at a rate of $237+220 \mathrm{~g}$ a.i. $\mathrm{ha}^{-1}$ have not controlled $\boldsymbol{B}$. pilosa. This weed is already reported as tolerant to ALS herbicides (NICOLAI et al., 2006), even though in this experiment it was controlled by diclosulam and cloransulam. The same authors reported that bentazon and fomesafen had an effective control of $\boldsymbol{B}$. pilos $\boldsymbol{a}$ corroborating with this experiment.

Digitaria spp. control was superior to all the treatments containing an inhibitor ACCase.
Imazethapyr and fomesafen controlled this specie as well (Table 1). BRIDGES \& STEPHENSON (1991) concluded that fomesafen at a rate of $400 \mathrm{~g}$ a.i. $\mathrm{ha}^{-1}$ had an effective control over Digitaria sanguinalis corroborating with this experiment. In contrast, BARROSO et al. (2010) reported that clethodim $\left(84 \mathrm{~g}\right.$ a.i. $\left.\mathrm{ha}^{-1}\right)$ and fluazifop $\left(125 \mathrm{~g}\right.$ a.i. ha $\left.{ }^{-1}\right)$ did not control Digitaria ciliaris at an acceptable level. It might have happened because $\boldsymbol{D}$. ciliaris was controlled at a growth stage of three tillers, which is more developed than in this experiment.

Parthenium hysterophorus was satisfactorily controlled by imazamox+bentazon, and treatments containing fomesafen, cloransulam and diclosulam (Table 1). REDDY et al. (2007) found a control of $26 \%$ at 21DAT of $\boldsymbol{P}$. hysterophorus with acifluorfen applied at rosette stage. In opposition, it was reported a control of $95 \%$ with chlorimuron, which might indicate susceptibility of this specie to ALS herbicides agreeing with what was observed in this experiment to cloransulam and diclosulam. However, in Brazil there are occurrence of ALS herbicide resistant biotypes (GRAZZIERO et al., 2006).

In the variable injury, there was interaction between cultivars and treatments at 14 DAT (Table 2).

Table 1 - Control (\%) of Bidens pilosa, Digitaria spp. and Parthenium hysterophorus based on the post-emergence herbicides at the beans crop, evaluated at 28 days after treatment. Vacaria-RS, 2015.

\begin{tabular}{|c|c|c|c|c|c|c|c|}
\hline \multirow{2}{*}{$\begin{array}{l}\text { Treatments } \\
\text { Bentazon }\end{array}$} & \multirow{2}{*}{$\begin{array}{c}\text { Rate }\left(\mathrm{g} \text { a.i. } \mathrm{ha}^{-1}\right) \\
720\end{array}$} & \multicolumn{2}{|c|}{----B. pilosa---- } & \multicolumn{2}{|c|}{----Digitaria spp. ---- } & \multicolumn{2}{|c|}{---P. hysterophorus-- } \\
\hline & & 100 & $a^{2}$ & 0 & d & 63 & $\mathrm{~b}$ \\
\hline Clethodim & 108 & 0 & c & 100 & $\mathrm{a}$ & 0 & $\mathrm{~d}$ \\
\hline Cloransulam & 17,5 & 96 & a & 0 & d & 98 & $\mathrm{a}$ \\
\hline Diclosulam & 35 & 93 & $\mathrm{a}$ & 41 & $\mathrm{c}$ & 99 & $\mathrm{a}$ \\
\hline Fomesafen & 250 & 100 & $\mathrm{a}$ & 89 & $\mathrm{a}$ & 100 & $\mathrm{a}$ \\
\hline Imazethapyr & 100 & 73 & $\mathrm{~b}$ & 80 & $\mathrm{a}$ & 70 & $\mathrm{~b}$ \\
\hline Clethodim+bentazon & $108+720$ & 70 & $\mathrm{~b}$ & 100 & $\mathrm{a}$ & 35 & $\mathrm{c}$ \\
\hline Clethodim+cloransulam & $108+17,5$ & 90 & $\mathrm{a}$ & 90 & $\mathrm{a}$ & 98 & $\mathrm{a}$ \\
\hline Clethodim+diclosulam & $108+35$ & 91 & a & 99 & $\mathrm{a}$ & 99 & a \\
\hline Clethodim+fomesafen & $108+250$ & 96 & $\mathrm{a}$ & 100 & $\mathrm{a}$ & 99 & $\mathrm{a}$ \\
\hline Clethodim+imazethapyr & $108+100$ & 66 & $\mathrm{~b}$ & 100 & $\mathrm{a}$ & 66 & $\mathrm{~b}$ \\
\hline Cloransulam+bentazon & $17,5+720$ & 88 & $\mathrm{a}$ & 0 & d & 99 & a \\
\hline Fomesafen+fluazifop & $250+250$ & 100 & $\mathrm{a}$ & 100 & $\mathrm{a}$ & 100 & a \\
\hline Imazamox+bentazon & $28+600$ & 97 & $\mathrm{a}$ & 13 & d & 94 & $\mathrm{a}$ \\
\hline Imazethapyr+bentazon & $100+720$ & 96 & a & 55 & $\mathrm{~b}$ & 80 & $\mathrm{~b}$ \\
\hline Weed-free control & - & 100 & $\mathrm{a}$ & 100 & $\mathrm{a}$ & 100 & $\mathrm{a}$ \\
\hline Weedy control & - & 0 & $\mathrm{c}$ & 0 & d & 0 & d \\
\hline $\mathrm{CV}(\%)^{3}$ & & & & & & & 39 \\
\hline
\end{tabular}

${ }^{1}$ Ttreatments containing clethodim, it was added the adjuvant Lanzar $^{\circledR}$ at $1 \% \mathrm{v} / \mathrm{v}$; to fomesafen+fluazifop, cloransulam and cloransulam+bentazon Break Thru ${ }^{\circledR}$ at $0,2 \% \mathrm{v} / \mathrm{v}$ and to imazamox+bentazon Assist ${ }^{\circledR}$ at $0,5 \% \mathrm{v} / \mathrm{v} ;{ }^{2}$ Means followed by different letters in a column differ statistically by the Scott \& Knott test $(\mathrm{P} \leq 0,05) ;{ }^{3} \mathrm{CV}=$ coefficient of variation. 
Table 2 - Visual injury (\%) based on the post-emergence herbicides at the beans crop, evaluated at 14 days after treatment, of the common beans cultivars 'ANfc 9', 'IPR Uirapuru' and 'BRS Estilo'. Vacaria-RS, 2015.

\begin{tabular}{|c|c|c|c|c|c|c|c|}
\hline \multirow{2}{*}{$\begin{array}{l}\text { Treatments }^{1} \\
\text { Bentazon }\end{array}$} & \multirow{2}{*}{$\begin{array}{c}\text { Rate }\left(\mathrm{g} \text { a.i. } \mathrm{ha}^{-1}\right) \\
720\end{array}$} & \multicolumn{2}{|c|}{ ANfc 9} & \multicolumn{2}{|c|}{ IPR Uirapuru } & \multicolumn{2}{|c|}{ BRS Estilo } \\
\hline & & 0 & $A^{2} d^{3}$ & 3 & $\mathrm{Ad}$ & 1 & $\mathrm{Ac}$ \\
\hline Clethodim & 108 & 0 & A d & 0 & $\mathrm{~A} \mathrm{e}$ & 0 & $\mathrm{Ac}$ \\
\hline Cloransulam & 17,5 & 6 & $\mathrm{~B} \mathrm{c}$ & 10 & $\mathrm{Ac}$ & 3 & $\mathrm{~B} \mathrm{~b}$ \\
\hline Diclosulam & 35 & 16 & $\mathrm{C} \mathrm{a}$ & 32 & A a & 25 & $\mathrm{~B}$ a \\
\hline Fomesafen & 250 & 1 & $\mathrm{Ad}$ & 1 & $\mathrm{~A} \mathrm{e}$ & 2 & $\mathrm{Ac}$ \\
\hline Imazethapyr & 100 & 5 & $\mathrm{Ac}$ & 8 & A c & 6 & $\mathrm{Ab}$ \\
\hline Clethodim+bentazon & $108+720$ & 2 & $\mathrm{~B} \mathrm{~d}$ & 9 & $\mathrm{Ac}$ & 0 & $\mathrm{~B} \mathrm{c}$ \\
\hline Clethodim+cloransulam & $108+17,5$ & 8 & $\mathrm{Ab}$ & 8 & $\mathrm{Ac}$ & 5 & $\mathrm{Ab}$ \\
\hline Clethodim+diclosulam & $108+35$ & 14 & $\mathrm{~B}$ a & 26 & $\mathrm{Ab}$ & 23 & $\mathrm{~A}$ a \\
\hline Clethodim+fomesafen & $108+250$ & 7 & $\mathrm{Ab}$ & 7 & $\mathrm{Ac}$ & 5 & $\mathrm{Ab}$ \\
\hline Clethodim+imazethapyr & $108+100$ & 5 & $\mathrm{~B} \mathrm{c}$ & 8 & $\mathrm{Ac}$ & 4 & $\mathrm{~B} \mathrm{~b}$ \\
\hline Cloransulam+bentazon & $17,5+720$ & 3 & $\mathrm{Ad}$ & 4 & $\mathrm{~A} \mathrm{~d}$ & 4 & $\mathrm{Ab}$ \\
\hline Fomesafen+fluazifop & $250+250$ & 4 & $\mathrm{Ac}$ & 3 & $\mathrm{Ad}$ & 2 & $\mathrm{Ac}$ \\
\hline Imazamox+bentazon & $28+600$ & 4 & $\mathrm{Ac}$ & 5 & $\mathrm{Ad}$ & 3 & $\mathrm{Ab}$ \\
\hline Imazethapyr+bentazon & $100+720$ & 7 & $\mathrm{Ab}$ & 8 & $\mathrm{Ac}$ & 3 & $\mathrm{~B} \mathrm{~b}$ \\
\hline Weed-free control & - & 0 & $\mathrm{Ad}$ & 0 & $\mathrm{Ae}$ & 0 & $\mathrm{Ac}$ \\
\hline Weedy control & - & 0 & $\mathrm{Ad}$ & 0 & $\mathrm{Ae}$ & 0 & $\mathrm{Ac}$ \\
\hline
\end{tabular}

${ }^{1}$ The treatments containing clethodim, it was added the adjuvant Lanzar ${ }^{\circledR}$ at $1 \% \mathrm{v} / \mathrm{v}$; to fomesafen+fluazifop, cloransulam and cloransulam+bentazon Break Thru ${ }^{\circledR}$ at $0,2 \% \mathrm{v} / \mathrm{v}$ and to imazamox+bentazon Assist ${ }^{\mathbb{B}}$ at $0,5 \% \mathrm{v} / \mathrm{v}$; ${ }^{2}$ Means of treatments into a cultivar followed by different lower case letters in a column differ statistically by the Scott \& Knott test $(\mathrm{P} \leq 0,05)$; ${ }^{3}$ Means of cultivars into a treatment followed by different upper case letters in a line differ statistically by the Scott $\&$ Knott test $(\mathrm{P} \leq 0,05)$; ${ }^{4} \mathrm{CV}=$ coefficient of variation.

Cultivars responded similarly to this variable, but the cultivar 'ANfc 9' have shown to be more resilient to ALS herbicides. Higher levels of visual injury were caused by treatments with diclosulam with all the cultivars.

Bentazon promotes a safening effect over ALS herbicides due to bentazon to actuate on the photosystem II (PSII) decreasing the ratio of photo assimilates production and translocation, thus, lowering the absorption rate and transportation of the ALS herbicides in the plant's phloem (BAUER et al., 1995b). This phenomenon was observed in this experiment with the treatment imazamox+bentazon in all the cultivars, cloransulam+bentazon in the cultivar 'ANfc 9' and 'IPR Uirapuru', which had lower visual injury compared to cloransulam alone (Table 2). However, it was not reported significant difference with the treatment imazethapyr isolated and tankmixed with bentazon in all three cultivars tested.

The treatments where fomesafen was tank-mixed with ACCase herbicides, and bentazon alone showed low level of injury and no injury, respectively (Table 2). Both herbicides controlled $\boldsymbol{B}$. pilosa, and Digitaria spp. when associated with an ACCase inhibitor herbicide. These results differ from
FONTES et al. (2001); and LINHARES et al. (2014) that reported fomesafen+fluazifop caused severe visual injury, reduced the plant's height, and low control level of dicot weeds. SOLTANI et al. (2013) and SOLTANI et al. (2005) reported that bentazon and fomesafen caused low crop injury at 14DAT.

The variable grain yield had the same response in all the three cultivars (Table 3). The response to the herbicide bentazon was conditioned to the herbicide associated, that is, when in association with imazamox it had higher grain yield, but when it was mixed with cloransulam, it decreased the grain yield being equivalent to bentazon alone on the cultivar 'ANfc 9'. Plots with clethodim isolated had similar performance of the non-treated weedy plot due to lack of broadleaf weed control.

The cultivar 'IPR Uirapuru' had best grain yield with an ACCase herbicide associated with fomesafen. Bentazon isolated or in association with clethodim or imazamox had the lowest grain yield for the cultivars 'IPR Uirapuru' and 'BRS Estilo', which was equivalent to the clethodim treatment due to poor weed control. The cultivar 'BRS Estilo' had its highest yield with fomesafen+fluazifop due to effective 
Table 3 - Grain yield $\left(\mathrm{kg} \mathrm{ha}^{-1}\right)$ of the common beans cultivars based on the post-emergence herbicides at the beans crop, cultivars 'ANfc 9', 'IPR Uirapuru' and 'BRS Estilo'. Vacaria-RS, 2015.

\begin{tabular}{|c|c|c|c|c|c|c|c|}
\hline \multirow{2}{*}{$\begin{array}{l}\text { Treatments }^{1} \\
\text { Bentazon }\end{array}$} & \multirow{2}{*}{$\frac{\text { Rate }\left(\mathrm{g} \text { a.i. ha }{ }^{-1}\right)}{720}$} & \multicolumn{2}{|c|}{ ANfc 9} & \multicolumn{2}{|c|}{ IPR Uirapuru } & \multicolumn{2}{|c|}{ BRS Estilo } \\
\hline & & 812,53 & $\mathrm{~A}^{2} \mathrm{c}^{3}$ & 198,33 & $\mathrm{~B} \mathrm{~d}$ & 495,48 & $\mathrm{~B} \mathrm{e}$ \\
\hline Clethodim & 108 & 304,22 & $\mathrm{~B} \mathrm{~d}$ & 142,68 & $\mathrm{Bd}$ & 592,21 & $\mathrm{Ae}$ \\
\hline Cloransulam & 17,5 & 1161,08 & $\mathrm{Ab}$ & 495,65 & $\mathrm{~B} \mathrm{c}$ & 1257,62 & $\mathrm{Ac}$ \\
\hline Diclosulam & 35 & 1173,69 & $\mathrm{Ab}$ & 624,18 & $\mathrm{~B} \mathrm{c}$ & 988,01 & $\mathrm{Ac}$ \\
\hline Fomesafen & 250 & 1405,69 & $\mathrm{~A}$ a & 1113,70 & $\mathrm{~B} \mathrm{~b}$ & 1475,91 & $\mathrm{Ac}$ \\
\hline Imazethapyr & 100 & 1229,30 & $\mathrm{Ab}$ & 807,39 & $\mathrm{~B} \mathrm{c}$ & 601,84 & $\mathrm{~B} \mathrm{e}$ \\
\hline Clethodim+bentazon & $108+720$ & 1330,28 & $\mathrm{Ab}$ & 352,41 & $\mathrm{Cd}$ & 888,20 & $\mathrm{~B} \mathrm{~d}$ \\
\hline Clethodim+cloransulam & $108+17,5$ & 1677,81 & $\mathrm{~A}$ a & 1207,62 & $\mathrm{~B} \mathrm{~b}$ & 1315,76 & $\mathrm{~B} \mathrm{c}$ \\
\hline Clethodim+diclosulam & $108+35$ & 1432,99 & $\mathrm{~A}$ a & 943,92 & $\mathrm{~B} \mathrm{~b}$ & 965,98 & $\mathrm{~B} \mathrm{~d}$ \\
\hline Clethodim+fomesafen & $108+250$ & 1424,11 & A a & 1574,01 & $\mathrm{~A}$ a & 1670,10 & $\mathrm{Ab}$ \\
\hline Clethodim+imazethapyr & $108+100$ & 1513,52 & $\mathrm{~A} \mathrm{a}$ & 1282,43 & $\mathrm{Ab}$ & 1277,72 & $\mathrm{Ac}$ \\
\hline Cloransulam+bentazon & $17,5+720$ & 939,72 & A c & 582,46 & A c & 817,42 & $\mathrm{Ad}$ \\
\hline Fomesafen+fluazifop & $250+250$ & 1538,60 & $\mathrm{~B}$ a & 1624,73 & $\mathrm{~B}$ a & 2021,56 & $\mathrm{~A} \mathrm{a}$ \\
\hline Imazamox+bentazon & $28+600$ & 1729,45 & $\mathrm{~A} \mathrm{a}$ & 545,02 & $\mathrm{Cc}$ & 1167,12 & $\mathrm{~B} \mathrm{c}$ \\
\hline Imazethapyr+bentazon & $100+720$ & 1082,49 & $\mathrm{~B} \mathrm{~b}$ & 1337,09 & $\mathrm{Ab}$ & 924,64 & $\mathrm{~B} \mathrm{~d}$ \\
\hline Weed-free control & - & 1402,09 & A a & 1323,47 & $\mathrm{Ab}$ & 1323,41 & $\mathrm{Ac}$ \\
\hline Weedy control & - & 372,06 & $\mathrm{Ad}$ & 251,73 & $\mathrm{Ad}$ & 307,29 & $\mathrm{Ae}$ \\
\hline $\mathrm{CV}(\%)^{4}$ & & ------- & ------. & 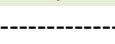 & $0,34-$ & 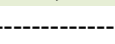 & ---- \\
\hline
\end{tabular}

${ }^{1}$ Ttreatments containing clethodim, it was added the adjuvant Lanzar ${ }^{\circledR}$ at $1 \% \mathrm{v} / \mathrm{v}$; to fomesafen+fluazifop, cloransulam and cloransulam+bentazon Break Thru ${ }^{\circledR}$ at $0,2 \% \mathrm{v} / \mathrm{v}$ and to imazamox+bentazon Assist ${ }^{\circledR}$ at $0,5 \% \mathrm{v} / \mathrm{v}$; ${ }^{2}$ Means of treatments into a cultivar followed by different lower case letters in a column differ statistically by the Scott \& Knott test $(\mathrm{P} \leq 0,05)$; ${ }^{3}$ Means of cultivars into a treatment followed by different upper case letters in a line differ statistically by the Scott \& $\mathrm{Knott}$ test $(\mathrm{P} \leq 0,05)$; ${ }^{4} \mathrm{CV}=$ coefficient of variation.

monocot and dicot weed control, and low crop injury. These results corroborated with MACHADO et al. (2006) and SOLTANI et al. (2013), which reported fomesafen as highly crop selective, not affecting negatively the grain yield.

The herbicide bentazon is reported as highly crop selective especially for common beans (BAUER et al., 1995b; SOLTANI et al., 2005; SOLTANI et al., 2013). The authors tested bentazon at rates varying from 960 to $2160 \mathrm{~g}$ a.i. $\mathrm{ha}^{-1}$, which are higher than the rates tested in this experiment, without affecting negatively common beans yield. However, this experiment have shown different results. Bentazon caused grain yield reduction for all the three cultivars due to ineffective weed control.

The cultivar 'ANfc 9' was more tolerant to the ALS herbicides compared to 'IPR Uirapuru' and 'BRS Estilo' (Table 3). This behavior difference is related to the cultivar genetics, which is controlled by quantitative genes that regulate leaf wax content and cuticle permeability, so it influences the rate of absorption and translocation of ALS herbicides throughout the plant (BAUER et al., 1995a). At the treatments with cloransulam tank-mixed with bentazon, yield was reduced compared to cloransulam alone for 'ANfc 9' and 'IPR Uirapuru'. The yield of imazethapyr tank-mixed with bentazon was higher in the cultivars 'IPR Uirapuru' and 'BRS Estilo' compared to imazethapyr alone. These results differ from SOLTANI et al. (2012) and SOLTANI et al. (2013), which reported a $12 \%$ yield increase on the treatment with cloransulam+bentazon against cloransulam alone. Whereas, BAUER et al. (1995b) reported that the treatment with imazethapyr tankmixed with bentazon assured the grain yield at the same level of the non-treated weed-free plot, opposing this experiment.

\section{CONCLUSION}

Broadleaf herbicides associated with ACCase inhibitor herbicides increase the weed control spectrum, without increasing considerably the crop injury levels at 14DAT. B. pilosa is controlled by all treatments containing broadleaf herbicides except imazethapyr. Digitaria spp. is controlled by all the treatments containing an ACCase inhibitor (clethodim or fluazifop), fomesafen and imazethapyr. 
P. hysterophorus is controlled by all the treatments containing the herbicides cloransulam, diclosulam, imazamox+bentazon and fomesafen.

Common beans cultivars have different patterns of crop injury. The cultivar 'ANfc 9' is the more resilient to the phytotoxic effects of ALS inhibitor herbicides such as imazethapyr, cloransulam and diclosulam, isolated or tank-mixed with clethodim than 'IPR Uirapuru' and 'BRS Estilo'; whereas, 'IPR Uirapuru' and 'BRS Estilo' present more symptoms of injury caused by ALS herbicides.

The cultivar 'ANfc 9' has higher grain yield with fomesafen treatments alone or tankmixed with clethodim or fluazifop, cloransulam, diclosulam and imazethapyr associated with clethodim, and imazamox+bentazon. The cultivar 'IPR Uirapuru' has higher grain yield with fomesafen tank-mixed with clethodim or fluazifop. The cultivar 'BRS Estilo' performed best with the herbicide fomesafen+fluazifop.

\section{REFERENCES}

AGROFIT (SISTEMA DE AGROTÓXOCOS FITOSSANITÁRIOS). Consulta de produtos formulados. Available from: <http://agrofit.agricultura.gov.br/agrofit cons/ principal_agro fit_cons $>$. Accessed: jun 27, 2015.

BARROSO, A.L.L. et al. Efficacy of ACCase-inhibiting herbicides in controlling grass weeds in soybeans crops. Planta Daninha, v.28, n.1, p.149-157, 2010. Available from: <http:// dx.doi.org/10.1590/S0100-83582010000100018>. Accessed: apr 20, 2015. doi: 10.1590/S0100-83582010000100018.

BAUER, T.A. et al. Pinto bean (Phaseolus vulgaris) varietal tolerance to imazethapyr. Weed Science, v.43, n.3, p.417-424, 1995a. Available from: <http://www.jstor.org/stable/4045574>. Accessed: sep 08, 2014. doi: 10.1614/WT-05-144.1.

BAUER, T.A. et al. 'Olathe' pinto bean (Phaseolus vulgaris) response to postemergence imazethapyr and bentazon. Weed Science, v.43, n.2, p.276-282, 1995b. Available from: <http:// www.jstor.org/stable/404549>. Accessed: sep 08, 2014.

BRIDGES, D.C., STEPHENSON, M.G. Weed control and tobacco (Nicotiana tabacun) tolerance with fomesafen. Weed Technology, v.5, p.868-872, 1991. Available from: $<$ http://www. jstor.org/stable/3986907>. Accessed: jun 25, 2016. doi: 10.1614/ WT-07-076.1.

CONSTANTIN, J. Métodos de manejo. In: OLIVERIRA JR, R.S. et al. Biologia e manejo de plantas daninhas. Curitiba. Omnipax, 2011. Chapter.3, p.67-78.

FONTES, J.R.A. et al. Effects of herbicides on weed control on mungbean [Vigna radiata (L.) WILCZEK]. Ciência Agrotécnica, v.25, n.5, p.1087-1096, 2001. Available from: <http://www.editora. ufla.br/index.php/component/phocadownload/category/43-volume-25numero-5?download=735:vol25numero5>. Accessed: sep 10, 2014.
GRAZZIERO, D.L.P. et al. Ragweed parthenium (Parthenium hysterophorus) cross-resistance to acetolactate synthase inhibiting herbicides. Planta Daninha, v.24, n.1, p.157-162, 2006. Available from: <http://dx.doi.org/10.1590/S0100-83582006000100020>. Accessed: oct 15,2014. doi: 10.1590/S0100-83582006000100020.

HEKMAT, S. et al. Effect of imazamox plus bentazon on dry bean (Phaseolus vulgaris L.). Crop protection, v.27, p.1491-1494, 2008. Available from: <http://www.sciencedirect.com/science/ article/pii/S0261219408001269>. Accessed: oct 21, 2014. doi: 10.1016/j.cropro.2008.07.008. doi: 10.1016/j.cropro.2008.07.008.

KOZLOWSKI, L.A. et al. Critical period of weed interference in the common bean crop under direct seeding system. Planta Daninha, v.20, n.2, p.213-220, 2002. Available from: <http:// dx.doi.org/10.1590/S0100-83582002000200007>. Accessed: oct 18, 2014. doi: 10.1590/S0100-83582002000200007.

LINHARES, C.M.S. et al. Growth cowpea under the effect of fomesafen and bentazon+imazamox. Revista Caatinga, v.27, n.1, p. 41-49, 2014. Available from: <http://200.137.6.4/revistas/index. php/sistema/article/view/2572/pdf_84>. Accessed: sep 18, 2014.

MACHADO, A.F.L. et al. Herbicide mixtures in weed management in bean culture. Planta Daninha, v.24, n.1, p.107114, 2006. Available from: <http://dx.doi.org/10.1590/S010083582006000100014>. Accessed: aug 20, 2014. doi: 10.1590/ S0100-83582006000100014.

NICOLAI, M. et al. Alternatives of management to the populations of Bidens pilosa and Bidens subaltenans resistant to the ALS inhibitors herbicides. Revista Brasileira de Herbicidas, v.5, n.3, p.72-79, 2006. Available from: <http://www.rbherbicidas.com. br/index.php/rbh/article/view/3>. Accessed: jun 19, 2016. doi: 10.7824/rbh.v5i3.3.

OLIVEIRA JR, R.S. Mecanismos de ação de herbicidas. In: OLIVEIRA JR, R.S. et al. Biologia e manejo de plantas daninhas. Curitiba. Omnipax, 2011. Chapter.7, p.141-192.

REDDY, K.N. et al. Ragweed parthenium (Parthenium hysterophorus) control with preemergence and postemergence herbicides. Weed technology, v.21, n.4, p.982-986, 2007. Available from: <http://www.bioone.org/doi/full/10.1614/WT-07053.1>. Accessed: jun 08, 2016. doi: 10.1614/WT-07-053.1.

SOLTANI, N. et al. Responses of black and cranberry beans (Phaseolus vulgaris) to post-emergence herbicides. Crop protection, v.24, p.15-21, 2005. Available from: <http://www. sciencedirect.com/science/article/pii/S0261219404001486>. Accessed: aug 20, 2014. doi: 10.1016/j.cropro.2004.06.003.

SOLTANI, N. et al. Weed management in white beans with postemergence herbicide tankmixes. Canadian Journal of Plant Science, v.93, p.669-674, 2013. Available from: <http:// www.nrcresearchpress.com/doi/abs/10.4141/cjps2012-273\#. VuHDvacrLIU>. Accessed: aug 20, 2014 . doi: 10.4141/ cjps2012-273.

SOLTANI, N. et al. Safening effect of bentazon on cloransulammethyl and halosulfuron-methyl in dry bean. Agricultural Sciences, v.3, n.3, p.368-374, 2012. Available from: <http:// www.scirp.org/journal/PaperInformation.aspx?PaperID=19036>. Accessed: aug 20, 2014. doi: 10.4236/as.2012.33043. 